\title{
THE
}

$10-2017$

\section{Divergent Responses in Growth and Nutritional Quality of Coastal Macroalgae to the Combination of Increased $\mathrm{pCO}_{2}$ and Nutrients}

Gordon T. Ober

Carol S. Thornber

University of Rhode Island, thornber@uri.edu

Follow this and additional works at: https://digitalcommons.uri.edu/nrs_facpubs

The University of Rhode Island Faculty have made this article openly available.

Please let us know how Open Access to this research benefits you.

This is a pre-publication author manuscript of the final, published article.

Terms of Use

This article is made available under the terms and conditions applicable towards Open Access

Policy Articles, as set forth in our Terms of Use.

Citation/Publisher Attribution

Ober, G., \& Thornber, c. (2017). Divergent responses in growth and nutritional quality of coastal macroalgae to the combination of increased $\mathrm{pCO}_{2}$ and nutrients. Marine Environmental Research, 131, 69-79. doi: 10.1016/j.marenvres.2017.09.003

Available at: http://dx.doi.org/10.1016/j.marenvres.2017.09.003

This Article is brought to you for free and open access by the Natural Resources Science at DigitalCommons@URI. It has been accepted for inclusion in Natural Resources Science Faculty Publications by an authorized administrator of DigitalCommons@URI. For more information, please contact digitalcommons-group@uri.edu. 
Divergent responses in growth and nutritional quality of coastal macroalgae to the combination of increased of $\mathrm{pCO}_{2}$ and nutrients

\author{
Gordon T Ober ${ }^{1}$ and Carol S. Thornber ${ }^{2}$ \\ ${ }^{1}$ WM Keck Sciences, Claremont McKenna College, Claremont, CA, USA, 91711 \\ ${ }^{2}$ Biological and Environmental Sciences, University of Rhode Island, Kingston, RI, USA \\ 02881
}




\begin{abstract}
:
Coastal ecosystems are subjected to global and local environmental stressors, including increased atmospheric carbon dioxide $\left(\mathrm{CO}_{2}\right)$ (and subsequent ocean acidification) and nutrient loading. Here, we tested how two common macroalgal species in the Northwest Atlantic (Ulva spp. and Fucus vesiculosus Linneaus) respond to the combination of increased $\mathrm{CO}_{2}$ and nutrient loading. We utilized two levels of $\mathrm{pCO}_{2}$ with two levels of nutrients in a full factorial design, testing the growth rates and tissue quality of Ulva and Fucus grown for 21 days in monoculture and biculture. We found that the opportunistic, fast-growing Ulva exhibited increased growth rates under high $\mathrm{pCO}_{2}$ and high nutrients, with growth rates increasing three-fold above Ulva grown in ambient $\mathrm{pCO}_{2}$ and ambient nutrients. By contrast, Fucus growth rates were not impacted by either environmental factor. Both species exhibited a decline in carbon to nitrogen ratios $(\mathrm{C}: \mathrm{N})$ with elevated nutrients, but $\mathrm{pCO}_{2}$ concentration did not alter tissue quality in either species. Species grown in biculture exhibited similar growth rates to those in monoculture conditions, but Fucus $\mathrm{C}: \mathrm{N}$ increased significantly when grown with Ulva, indicating an effect of the presence of Ulva on Fucus. Our results suggest that the combination of ocean acidification and nutrients will enhance abundance of opportunistic algal species in coastal systems and will likely drive macroalgal community shifts, based on species-specific responses to future conditions.
\end{abstract}

Key words: ocean acidification, eutrophication, climate change, macroalgae, nutritional quality 


\section{Introduction}

Increasing amounts of carbon dioxide $\left(\mathrm{CO}_{2}\right)$ in the earth's atmosphere are the driving force behind global climate change (Pachauri et al., 2014). Ocean acidification, a decrease in $\mathrm{pH}$ brought about by increased atmospheric $\mathrm{CO}_{2}$, has garnered attention due to the overwhelmingly negative effects predicted for calcifying organisms (Comeau et al., 2014; Diaz-Pulido et al., 2011; Hoegh-Guldberg et al., 2007; Waldbusser et al., 2015). Changes in ocean chemistry associated with ocean acidification, such as lowered saturation states, are causing reductions in growth, increased shell dissolution, and declines in fitness and performance of many marine calcifying species (Ries et al., 2009; Waldbusser et al., 2015). Ocean acidification has also been shown to impact the growth, development, and sensory systems in fish (Frommel et al., 2016; Munday et al., 2009).

Conversely, less attention has been paid to non-calcifying autotrophic organisms. These species may benefit from ocean acidification and the subsequent change in ocean chemistry, as increased concentrations of both aqueous $\mathrm{CO}_{2}$ and bicarbonate $\left(\mathrm{HCO}_{3}\right)$ may enhance photosynthesis and growth in primary producers. Enhanced growth rates under increased $\mathrm{CO}_{2}$ conditions have been observed in fleshy macroalgae (Kübler et al., 1999; Olischläger and Wiencke, 2013; Diaz-Pulido et al., 2011; Zou, 2005, p. 200; Kroeker et al., 2010) and seagrasses (Zimmerman et al., 1997). However, the response of primary producers to increased $\mathrm{CO}_{2}$ is highly species specific, ultimately dependent on carbon limitation and carbon acquisition ability as well as developmental stage (Gaitán-Espitia et al., 2014; Olischläger et al., 2012). As such, negative and neutral responses to $\mathrm{CO}_{2}$ enrichment have also been observed (Gutow et al., 2014; Rautenberger et al., 2015). Divergent responses of fleshy macroalgae to $\mathrm{CO}_{2}$ enrichment are correlated with the 
presence and efficiency of the carbon concentrating mechanism (CCM) (Giordano et al., 2005; Raven and Beardall, 2003). Due to highly abundant bicarbonate ions, most macroalgae rely on $\mathrm{CCMs}$ to convert $\mathrm{HCO}_{3}$ to $\mathrm{CO}_{2}$ for use in photosynthesis (Hepburn et al., 2011). In addition, many species also have the ability to passively diffuse $\mathrm{CO}_{2}$ and may gain an advantage under future conditions due to reduced reliance and downregulation of CCMs. While most marine macroalgae have CCMs, a few species within the Rhodophyta rely on passive diffusion of $\mathrm{CO}_{2}$ for photosynthesis (Giordano et al., 2005; Raven and Beardall, 2003). These species, among others, should experience enhanced growth and photosynthesis due to the increased concentration of $\mathrm{CO}_{2}$ associated with ocean acidification.

While ocean acidification is projected to impact all marine systems, the effects will likely vary across ecosystems (Hofmann et al. 2011). The signal of ocean acidification is easy to determine in the open ocean. Unlike in the open ocean, coastal $\mathrm{pH}$ is highly variable due to daily and seasonal shifts in photosynthesis and respiration, and coastal acidification may be driven more by eutrophication than increases in atmospheric $\mathrm{CO}_{2}$ (Cai et al., 2011). In coastal and estuarine environments of the northwest Atlantic, daily $\mathrm{pH}$ variation ranges from 0.1 to 0.65 units, depending on the location and season (Turner, 2015). Nutrient loading (and potential eutrophication events) also impacts coastal bays and estuaries with low flow and low turnover (Lee and Olsen, 1985). Nutrients can enter these waterways via agricultural and urban runoff and sewage treatment discharge, pumping excess nitrogen and phosphorous into the water column (Nixon, 1995). While these nutrients are critical to algal growth, excess concentrations can facilitate harmful algal blooms, either composed of micro and/or macroalgae 
(Anderson et al., 2002) whose decomposition or respiration can lower oxygen levels in the water column potentially leading to hypoxic events, with detrimental impacts on coinhabitants (Granger et al., 2000; Thomsen et al., 2006; Valiela et al., 1997). Macroalgal blooms can also act as a deterrent to coastal recreation (Valiela et al., 1997; Worm and Lotze, 2006).

Our understanding of climate effects on coastal zones is critical, as these ecosystems hold high value in biodiversity as well as economic and societal importance (Harley et al., 2006). Increased $\mathrm{CO}_{2}$, combined with increased concentrations of limiting nutrients, could act in conjunction to stimulate and enhance growth in primary producers. While acidification studies are beginning to incorporate additional environmental stressors such as light intensity and warming (Olischläger and Wiencke, 2013; Rautenberger et al., 2015; Roleda et al., 2012; Sarker et al., 2013), the combined effects of acidification and nutrients on primary producers are less understood (but see Campbell and Fourqurean, 2014; Falkenberg et al., 2013; Russell et al., 2009).

In coastal ecosystems, the green macroalga Ulva and the brown macroalga Fucus have different life history and ecological traits. Ulva is a fast-growing, opportunistic, ephemeral genus that thrives in a wide range of environments. Fucus is a long-lived, slow growing, perennial genus that creates complex, three-dimensional habitat for other organisms. These genera, among others, form the base of coastal marine food webs in the northwest Atlantic and are commonly grazed by herbivores and omnivores (Bracken et al., 2014; Lubchenco, 1983; Watson and Norton, 1985). Both genera use CCMs (Koch et al., 2013), but exhibit divergent responses, with increased growth rates for Ulva lactuca and decreased growth rates for Fucus vesiculosus under high $\mathrm{CO}_{2}$ conditions (Gutow et 
al., 2014; Olischläger et al., 2013). Similarly, Ulva lactuca has increased growth rates under high nutrients (Steffensen, 1976). Fucus vesiculosus experiences a reduction in growth and cover due to the indirect effects of added nutrients, such as increased turbidity and increased growth of epiphytic algae (Berger et al., 2004).

The objective of our research was to quantify the interaction of $\mathrm{CO}_{2}$ and nutrients on Ulva spp. and F. vesiculosus found in Narragansett Bay, RI, by assessing growth rates, tissue quality (tissue $\mathrm{C}: \mathrm{N}$ ratio), carbon and nitrogen content of algal tissues, and potential competitive effects. In the coastal ecosystems, perennial Fucus spp. can grow in high densities in the intertidal and shallow subtidal zones, up to 4,000 plants $/ \mathrm{m}^{2}$ (Creed et al., 1996). In Narragansett Bay, Fucus spp. can account for 5-20\% of year round algal cover, whereas during the growing season, Ulva spp. density can range from $5-75 \mathrm{~g} / \mathrm{m}^{2}$ (Guidone et al., 2013). While U. lactuca was chosen for this study, recent invasions of the cryptic U. australis have nullified our initial identification (Guidone et al., 2013; Hofmann et al., 2010). It is likely that the tested specimens are a mix of two species: $U$. lactuca and $U$. australis. We will hereafter refer to our test organisms as Ulva and Fucus. We predicted that the growth rate and tissue quality of Ulva would increase with extreme $\mathrm{pCO}_{2}$ levels and increased nutrients, and the combination of the two environmental factors would result in a synergistic effect on its growth rate (Neori et al., 1991; Russell et al., 2009). By contrast, we predicted that extreme levels of $\mathrm{pCO}_{2}$ will decrease the growth rate of Fucus, which is likely to occur due to potential $\mathrm{pH}$ sensitivity of its CCM (Axelsson et al., 2000; Gutow et al., 2014), but increase tissue quality (as seen in Gutow et al., 2014). We hypothesized that Fucus growth would be unaffected by nutrient loading as this species has lower nutrient uptake rates and is typically adapted to 
lower nutrient environments (Savage and Elmgren, 2004), and nutrients may indirectly reduce growth rates by promoting the growth of competitors (Hemmi et al., 2005; Pedersen and Borum, 1996; Worm and Lotze, 2006). Growth rates and tissue quality of both Ulva and Fucus were tested in a biculture experiment to inform community response, where we expect opportunistic Ulva to outgrow Fucus resulting in lower growth rates and tissue quality of Fucus (Connell and Russell, 2010; Falkenberg et al., 2013; Worm and Lotze, 2006). We interpret our results in the context of macroalgal response to climate change and future ecosystem structure.

\section{Materials and Methods}

\subsection{Algal Collection and Experimental Design}

We conducted experiments using the flow-through seawater facility at the US Environmental Protection Agency Atlantic Ecology Division in Narragansett, RI (Ulva monoculture - September 2014, Fucus monoculture - November 2014, and biculture October 2014). First, thalli of Ulva and Fucus were collected from the shallow subtidal zone at the University of Rhode Island's Narragansett Bay Campus beach (41'29'26”N, $71^{\circ} 25^{\prime} 11^{\prime \prime} 4 \mathrm{~W}$ ) in August 2014, September 2014, and October 2014. While much of the Fucus population at this site remains strictly intertidal, Fucus can thrive in the lower intertidal and shallow subtidal (Lubchenco, 1983). As our experiments did not replicate tidal cycles, it was critical that the collected Fucus came from the shallow subtidal in order to not introduce stress associated with full-time immersion. In order to capture the sites of Fucus growth (Moss, 1967), non-reproductive tips of Fucus ( 3-5cm in length) were cut from adult thalli. Apical tips of Fucus used in experiments were taken from 
unique adult thalli, so that each tip came from a different individual and that tips were not clones of one another. Fucus tips and Ulva thalli were cleaned of any epiphytes, and transferred into separate 20L glass aquaria with flow-through seawater and aeration. Algal individuals (Ulva thalli and Fucus tips) were acclimated to lab conditions for five days prior to the start of each experiment.

To set up experiments, we first spun algae $20 \times$ in a salad spinner (Thornber et al., 2008 ), removed a small piece ( $\sim 10 \%$ of starting mass) of the thallus which was then dried at $60^{\circ} \mathrm{C}$ for $24 \mathrm{~h}$ and then placed in a desiccator for $\mathrm{C}: \mathrm{N}$ analysis (see below), and then recorded the initial algal wet mass of each remaining piece. We placed individuals into 20L aquaria with one individual per tank (for monocultures) or one individual of each species (for the biculture experiment). Starting sizes of all test individuals were about the same size (3-5 cm in length) but due to physical and structural differences in the two species the starting wet mass differed. Starting wet mass was $0.40 \mathrm{~g}$ and $0.55 \mathrm{~g}$ for Ulva and Fucus, respectively. Based on these starting masses and tank volumes, the density of macroalgae was $5.6 \mathrm{~g} / \mathrm{m}^{2}$ in the Ulva monoculture, $7.72 \mathrm{~g} / \mathrm{m}^{2}$ in the Fucus monoculture, and about $13.5 \mathrm{~g} / \mathrm{m}^{2}$ in the biculture experiment.

Narragansett Bay has high variation in $\mathrm{pCO}_{2}$ and $\mathrm{DIN}$ on both spatial and temporal scales. Annual average $\mathrm{pCO}_{2}$ concentration is around $400 \mu \mathrm{atm}$ but ranges from $150-1000 \mu$ atm (Turner, 2015). DIN in Narragansett Bay runs along a north south gradient, where water has an annual average of $70 \mu \mathrm{M} \mathrm{DIN}$ (with nitrate, $\mathrm{NO}_{3}{ }^{-}$, with annual peaks reaching concentrations greater than $40 \mu \mathrm{M}$ ) in the north and annual average of 4-10 $\mu \mathrm{M}$ DIN in the south (location of collected specimens), where certain parts of the bay can exceed $180 \mu \mathrm{M}$ DIN (Krumholz, 2012). We experimentally tested the 
response of algae to four environmental treatments, which factorally combined two levels of $\mathrm{pCO}_{2}$ enrichment (ambient $\sim 400 \mu$ atm $\mathrm{pCO}_{2}$, and extreme projections for the year $2100 \sim 1100 \mu \mathrm{atm} \mathrm{pCO}_{2}$, values aimed at, or slightly higher than, concentration pathway 8.5 (RCP8.5) projections; Moss et al., 2010) and two levels of nutrient loading (ambient $\sim 4 \mu \mathrm{M}$ nitrate, and high $\sim 80 \mu \mathrm{M}$ nitrate). Each of the four environmental treatments had a 40L headwater tank where $\mathrm{CO}_{2}$ gas or ambient outdoor air (depending on the treatment) was bubbled in at a constant rate. We obtained high $\mathrm{pCO}_{2}$ by bubbling in pure $\mathrm{CO}_{2}$ gas via an Aalborg Mass Flow Controller GFC (Aalborg Instruments and Controllers, INC) into the headwater tank. Filtered, tempered seawater $\left(18^{\circ} \mathrm{C}\right.$, kept constant) was pumped into headwater tanks to mix with $\mathrm{CO}_{2}$ or air. Mixing of gas and water was aided via a Hydor Circulation Fan. Treated water was pumped from the headwater tank via an Eheim 1200 submersible pump to a manifold, delivering treated water to seven experimental aquaria for each treatment. Aquaria received water at a rate of $130 \pm 5 \mathrm{~mL} / \mathrm{min}$, using a flow-through design we captured the natural variability of coastal $\mathrm{pH}$ that can fluctuate up to about 0.4 units at this location (Turner, 2015). Here, all experimental aquaria were exposed to the same amount of natural, daily variability, with $\mathrm{pCO}_{2}$-treated aquaria starting at a reduced $\mathrm{pH}$.

Nutrients were added individually to each experimental aquarium, as appropriate, through slow-release agar blocks (Teichberg et al., 2010). Blocks were created to meet the desired nutrient concentration ( $\sim 80 \mu \mathrm{M}$ nitrate, $\sim 80 \mu \mathrm{M}$ ammonia, $\sim 4 \mu \mathrm{M}$ phosphate for the 20L aquaria) by adding nitrate and ammonium, in the form of $\mathrm{KNO}_{3}$ (at $2 \mathrm{M}$ concentration) and $\mathrm{NH}_{4} \mathrm{CL}$ (at $2 \mathrm{M}$ concentration), along with $3 \%$ agar and seawater (Tate, 1990). Phosphate was added to the blocks, in the form of $\mathrm{KH}_{2} \mathrm{PO}_{4}$ (at $1 \mathrm{M}$ 
concentration). Blocks containing only agar and seawater were added to the ambient nutrient tanks in order to simulate the physical addition of the block. To create the blocks, nutrients, seawater, and agar were thoroughly mixed and heated, then $50 \mathrm{~mL}$ of mixture was poured into a petri dish and chilled for $24 \mathrm{hrs}$. Once solid, blocks were divided into fourths, and each experimental tank received the block segment. Block segments were hung in mesh bags within the tanks to ensure consistent dissolution, with full dissolution of segments taking $\sim 4$ weeks (Ober, personal observations). Water flow into experimental aquaria was measured at a rate of $150 \mathrm{~mL} / \mathrm{min}$, meaning water in each tank turned over at a rate of about once every $2.25 \mathrm{~h}$, this flow rate was controlled and kept consistent for each aquaria. Prior testing of block concentrations, size, and tank flow ensured that water in each nutrient-enriched aquaria remained within $10 \mu \mathrm{M}$ of desired concentrations. These concentrations remained consistent despite species-specific differences in uptake rates. Seawater nutrient levels were analyzed at the beginning of the experiment and midway through the experiment. $60 \mathrm{~mL}$ samples of seawater were filtered (GF/F) and frozen prior to analysis. Seawater samples were analyzed for nitrate and phosphate by the URI Marine Science Research Facility, an RI NSF EPSCoR Core Facility (Table 1).

Each experiment ran for a total of 21 days, and tanks were supplemented with artificial light (Sylvania Full Spectrum) at $172.4 \pm 30 \mu \mathrm{mol}$ photons $\mathrm{m}^{-2} \mathrm{sec}^{-2}$ with a light/dark rhythm of 14:10h (L:D). Light levels were slightly under saturation for both Ulva $\left(\sim 200 \mu \mathrm{mol}\right.$ photons $\left.\mathrm{m}^{-2} \mathrm{sec}^{-2}\right)$ and Fucus $\left(\sim 300 \mu \mathrm{mol}\right.$ photons $\left.\mathrm{m}^{-2} \mathrm{sec}^{-2}\right)$, but levels used in this study were high enough to remove undersaturation as a factor in growth (Bäck and Ruuskanen, 2000; Rautenberger et al., 2015; Rohde et al., 2008). Tanks were 
scrubbed and cleaned every two days and any epiphytes growing on the algae were removed. Every seven days, algae were briefly removed, weighed, and a small piece $(<10 \%$ of total wet mass) was removed for future $\mathrm{C}: \mathrm{N}$ analysis. Mass of removed tissue was included in the calculation of total growth; however, this likely resulted in an underestimation of total algal growth. Algal tissue quality was determined by drying tissue samples for $24 \mathrm{~h}$ at $60^{\circ} \mathrm{C}$. All dried samples were preserved in glass vials and placed in a desiccation chamber. Samples were ground into a powder and placed in tin capsules. All samples were analyzed for carbon and nitrogen concentrations by Dr. Brad S. Moran's laboratory at the University of Rhode Island Graduate School of Oceanography using an Exeter Analytical CE-440 elemental analyzer.

\subsection{Carbonate Chemistry}

Temperature, salinity, dissolved inorganic carbon (DIC), and total alkalinity (TA) were sampled during each experiment following the Best Practices Guide (Dickson et al., 2007). For each experiment, water samples were taken twice weekly from a random subset of tanks from each treatment, with sampling occurring midday (resulting in two to four total water samples per week per treatment). Samples were bottled and preserved with mercuric chloride $\left(\mathrm{HgCl}_{2}\right)$ and then analyzed for DIC using a Shimadzu DIC gas chromatograph. TA was calculated for each sample using a Metrohm 877 Titrino plus titrator. Carbonate chemistry for experimental tanks (Table 1) was calculated using CO2SYS (Pierrot et al., 2006) using TA, DIC, salinity, and temperature with constants from Mehrbach et al. (1973). Calculated values for $\mathrm{pH}$ are reported on the seawater scale. In addition, $\mathrm{pH}$ and temperature were logged for each treatment throughout the course of 
the experiment using a WTW Profiline $\mathrm{pH}$ meter with glass electrode and HOBO temperature logging pendants, respectively, with $\mathrm{pH}$ recorded to help indicate daily fluctuations. All data presented in Table 1 are representative of midday values. Due to high flow rates and large aquaria, algal metabolism did not impact seawater carbonate chemistry (Roleda et al., 2015). In addition, the $\mathrm{pH}$ of experimental tanks were periodically compared with "blank tanks" (ones without algal cultures but receiving the same environmental treatments) to ensure that algal metabolism wasn't altering the environmental parameters.

\subsection{Statistical Analysis:}

Relative growth rate $\left(\mathrm{RGR}, \% \mathrm{day}^{-1}\right.$ ) was calculated for each alga based on change in wet mass between the start and end of each experiment. Mean RGR, final carbon and nitrogen concentrations, and final $\mathrm{C}: \mathrm{N}$ ratios for each species were assessed using two-way analyses of variance (ANOVA) with $\mathrm{pCO}_{2}$ and nutrient level fixed factors. Initial C:N ratios of either species did not differ among environmental treatments (two-way ANOVA, $\mathrm{p}>0.05$ ). As Ulva's growing season does not extend into northern hemisphere winters, time was a significant restraint in our experimental design and did not allow for us to simultaneously run biculture and monoculture experiments thus making comparisons of results more difficult. However, critical environmental conditions, as well as experimental parameters, were purposely kept consistent between experiments (Table 1) in effort to assess differences between results in monoculture and biculture experiments. Initial tissue concentrations of $\mathrm{C}$ and $\mathrm{N}$ for monoculture and biculture experiments were compared using a one-way ANOVA (with culture as a fixed 
factor) for both algal species. There was no significant difference in initial $\mathrm{C}: \mathrm{N}$ ratios in algal tissues for both species (one-way ANOVA, Ulva: $\mathrm{F}_{1,42}=0.77, \mathrm{p}=0.38 ;$ Fucus: $\mathrm{F}_{1,43}$ $=0.11, \mathrm{p}=0.75)$. Therefore, we compared final tissue $\mathrm{C}: \mathrm{N}$ between monoculture and biculture experiments using a one-way ANOVA to determine whether culture influenced tissue-level response of macroalgae. By including culture as a factor in our analysis, we aim to understand how species might be affecting one another, but understand that our experimental design does not itself test competition. Here, using culture as a factor can help point to effects of one species on another. All statistical analyses were performed using JMP v 11 (www.jmp.com).

\section{Results}

\subsection{Algal Growth}

Ulva grown in monoculture under high $\mathrm{pCO}_{2}$ and high nutrients had nearly a threefold faster relative growth rate (RGR) than monoculture Ulva grown under ambient conditions $\left(7.5 \pm 0.33 \%\right.$ day $^{-1}$ vs. $2.83 \pm 1.06 \%$ day $^{-1}$, respectively; Fig. $\left.1 \mathrm{~A}\right)$. RGR of Ulva grown in monoculture was significantly increased by elevated $\mathrm{pCO}_{2}$ and elevated nutrients ( $p=0.005, p=0.002$, respectively; Table $2 a)$, with no significant interaction.

We did not observe an effect of $\mathrm{pCO}_{2}(\mathrm{p}=0.50$; Table $2 \mathrm{a})$ or nutrient level $(\mathrm{p}=$ 0.52; Table 2a) on the RGR of Fucus grown in monoculture, as rates ranged from $1.91 \pm$

0.17 to $2.16 \pm 0.20 \%$ day $^{-1}$ (Fig. 1C), with a non-significant interaction $(p=0.45$; Table 2a).

We observed similar growth rates of Ulva and Fucus between monoculture and biculture experiments. Ulva grown in biculture under high $\mathrm{pCO}_{2}$ and high nutrients 
experienced a similar threefold increase in RGR compared to individuals grown under ambient conditions ( $7.6 \pm 0.55 \%$ day $^{-1}$ vs. $2.3 \pm 1.4 \%$ day $^{-1}$, respectively; Fig. 1B). The observed range of RGR across treatments of Fucus grown in biculture, $1.99 \pm 0.17$ and $2.18 \pm 0.11 \%$ day $^{-1}$ (Fig. 1D), were comparable to the range found in monoculture experiments. Elevated $\mathrm{pCO}_{2}$ and elevated nutrients significantly increased the RGR of bicultured Ulva $(\mathrm{p}=0.012, \mathrm{p}=0.002$, respectively; Table $2 \mathrm{~b})$ with no significant interaction. RGR of bicultured Fucus was unaffected by environmental treatment, maintaining similar rates of growth regardless of nutrient or $\mathrm{pCO}_{2}$ level (Table 2b).

\subsection{Algal Tissue Content (C:N, C, N)}

The C:N of both Ulva and Fucus grown in monoculture was significantly lower under high nutrient treatments ( $<<0.0001$ and $p=0.002$, respectively; Table 3a; Fig. 2). With elevated nutrients, mean C:N in Ulva was measured at 14.81 compared to a mean of 19.82 under ambient nutrients. Mean C:N within Fucus grown under high nutrients was measured at 19.59 compared to a mean of 23.72 under ambient nutrient conditions. By contrast, $\mathrm{pCO}_{2}$ did not significantly affect the $\mathrm{C}: \mathrm{N}$ of either Ulva or Fucus $(\mathrm{p}=0.64, \mathrm{p}=$ 0.11 , respectively; Table 3a), with non-significant $\mathrm{pCO}_{2} \times$ nutrient interactions (Table 3a).

Carbon concentration within tissues of Ulva and Fucus were significantly higher under high $\mathrm{pCO}_{2}(\mathrm{p}=0.03, \mathrm{p}=0.05$, respectively; Table 3a, Fig. 3A and 3B). Similarly, nitrogen concentration in both Ulva and Fucus tissues increased under high nutrient treatments ( $p=0.02, p=0.04$, respectively; Table 3a, Fig. 3A and 3B). 
Tissues of Ulva and Fucus grown in biculture were similarly affected by nutrient addition as those grown in monoculture. Here, increased nutrients lead to significant decreases in C:N for both species (Ulva: $\mathrm{p}=0.03$; Fucus: $\mathrm{p}=0.0002$; Table 3b). Tissue $\mathrm{C}: \mathrm{N}$ for both species was not affected by $\mathrm{pCO}_{2}$ level and no significant interaction was observed between nutrients and $\mathrm{pCO}_{2}$ (Table $3 \mathrm{~b}$ ). Elevated nutrients also resulted in increased concentrations of nitrogen in the tissues of both Ulva and Fucus $(\mathrm{p}=0.01, \mathrm{p}=$ 0.03 , respectively; Table $3 b$ ). In addition, elevated nutrients resulted in significantly higher concentrations of carbon in the tissues of Ulva growing in biculture $(\mathrm{p}=0.02$; Table 3b).

\subsection{C:N in Monoculture vs. Biculture}

As initial C:N did not differ for either Ulva or Fucus between treatments and culture experiments, we compared final C:N between monoculture and biculture treatments for both species. We found that culture significantly impacted the C:N of Fucus tissue ( $\mathrm{F}_{1,43}$ $=8.02, \mathrm{p}=0.007)$, where Fucus grown in had higher $\mathrm{C}: \mathrm{N}$ ratios than Fucus grown in monoculture. Monocultured Fucus had a mean C:N of 20.40 compared to a mean of 23.25 under biculture. Alternatively, tissue C:N of Ulva was not altered by culture as ratios did not differ between monoculture and biculture treatments $\left(\mathrm{F}_{1,42}=1.13, \mathrm{p}=0.30\right)$.

\section{Discussion}

\subsection{Algal Growth}

Non-calcifying primary producers are predicted to benefit from changes in seawater chemistry due to ocean acidification (see Kroeker et al., 2013). We 
hypothesized that $U l v a$ would be significantly impacted by $\mathrm{pCO}_{2}$ and experience increased growth rates. Our results support this hypothesis as we found that Ulva growth rates doubled under $1100 \mu \mathrm{atm} \mathrm{pCO}_{2}$ conditions. This matches the response of Ulva to ocean acidification in other systems (Olischläger et al., 2013; Xu and Gao, 2012) as well as other macroalgal species (Campbell and Fourqurean, 2014; Kübler et al., 1999; Olischläger and Wiencke, 2013; Swanson and Fox, 2007). Olischläger et al. (2013) observed a doubled growth rate of $U$. lactuca when exposed to $700 \mu$ atm $\mathrm{pCO}_{2}$, and $\mathrm{Xu}$ and Gao (2012) found $U$. prolifera exhibited increased growth rates of about $40 \%$ when exposed to $1000 \mu \mathrm{atm} \mathrm{pCO}_{2}$. These studies used concentrations of $\mathrm{pCO}_{2}$ expected in the next 50-100 years, whereas our study focused on the more extreme $\mathrm{pCO}_{2}$ projection for the year 2100. However, the response of macroalgae is still highly species-specific, and neutral or negative impacts of ocean acidification on growth rate have been observed in non-calcifying macroalgae (Cornwall et al., 2012; Gutow et al., 2014; Israel and Hophy, 2002; Mercado and Gordillo, 2011). Divergent responses of macroalgae to acidification are likely due to the differences in CCM effectiveness, potentially giving certain species more independence from the environment, or CCMs are optimized for higher $\mathrm{pH}$ conditions and their activity is sensitive to $\mathrm{pH}$ (Axelsson et al., 2000; Moulin et al., 2011).

How Ulva takes advantage of increased $\mathrm{CO}_{2}$ may be due to changes in physiological processes, such as down-regulation of CCM activity and reallocation of energy, increased nitrogen assimilation, and/or slight increases in photosynthetic activity (Olischläger et al., 2013; Xu and Gao, 2012). Algal species that lack CCMs are predicted to have increased photosynthetic activity under high $\mathrm{pCO}_{2}$ conditions, as these species 
are carbon limited (Kübler et al., 1999). Ulva, however, has a highly efficient CCM and does not appear carbon limited (Axelsson et al., 1999, 1995). Xu and Gao (2012) offer a few mechanisms for the success of Ulva under high $\mathrm{pCO}_{2}$ environments, in which photochemical and photorespiratory pathways are mediated. However, it is important to note that although we discuss ocean acidification as an increase in $\mathrm{pCO}_{2}$, there is also an increase in the amount of $\mathrm{HCO}_{3}{ }^{-}$available under these conditions. In our experiments, we observed greater concentrations of $\mathrm{HCO}_{3}{ }^{-}$when we increased $\mathrm{pCO}_{2}$ (Table 1). As Ulva primarily uses $\mathrm{HCO}_{3}{ }^{-}$, the enhanced growth we observe in this species under high $\mathrm{pCO}_{2}$ conditions may very well be tied to $\mathrm{HCO}_{3}{ }^{-}$rather than $\mathrm{CO}_{2}$. Fernández et al. (2015) found evidence of greater $\mathrm{HCO}_{3}{ }^{-}$use as an inorganic carbon source for photosynthesis in Macrocystis pyrifera. Photosynthetic rates of Ulva, as determined by oxygen production, increased by a factor of 1.2 under $700 \mu \mathrm{atm} \mathrm{pCO}_{2}$, but this increase was not statistically significant (Olischläger et al., 2013). Conversely, Rautenberger et al. (2015) found that light levels drive photosynthetic activity and growth in $U$. rigida, not high $\mathrm{pCO}_{2}$, and light and nutrients are typically cited as the most important factors influencing growth in Ulva spp. (Aldridge and Trimmer, 2009; Coutinho and Zingmark, 1993).

Our prediction that the growth rate of Fucus would decrease under high $\mathrm{pCO}_{2}$ (e.g. Gutow et al. 2014) was not validated. Similar to Ulva, Fucus utilizes a CCM to help convert and supply sites of photosynthesis with usable carbon, but Fucus species have an internal store of usable carbon and thus are not as sensitive to changes in carbon chemistry (Kawamitsu and Boyer, 1999). It is possible that long-lived species such as Fucus may respond more slowly (e.g. months vs. weeks) to an altered environment. 
Pedersen and Borum (1996) found that fast-growing species, like Ulva, exhibit increased growth rates with increased nutrient concentrations and exhibit increased uptake rates (Pederson and Borum, 1997), unlike Fucus, which has lower uptake rates. Pedersen and Borum (1996) also highlight a much higher nutrient uptake rate in Ulva (fitting a hyperbolic curve with increasing nutrient concentrations) compared to Fucus. Inorganic nitrogen was added as a factor in the form of both nitrate $\left(\mathrm{NO}_{3}{ }^{-}\right)$and ammonium $\left(\mathrm{NH}_{4}{ }^{+}\right)$ in relatively equal concentrations. As a fast-growing, ephemeral species, Ulva has a higher nitrogen demand to reach maximum growth compared to Fucus, a slow growing species (Pederson and Borum, 1997). Nutrient uptake kinetics in Ulva highlight asymptotic uptake of both $\mathrm{NO}_{3}{ }^{-}$and $\mathrm{NH}_{4}{ }^{+}$, where uptake slows between 20 and $40 \mu \mathrm{M}$ (Pederson and Borum, 1997; Rees et al., 2007), pointing to saturation. Here, our tested values of $\mathrm{NO}_{3}{ }^{-}$and $\mathrm{NH}_{4}{ }^{+}$fall above expected saturation levels, and perhaps Ulva growth under our treatment levels would be the same even if nutrients were half of what we tested. Young and Gobler (2016) elevated $\mathrm{NO}_{3}{ }^{-}$to $50 \mu \mathrm{M}$ but found that this level of nutrient addition only significantly increases Ulva growth rates in seasons where nutrient levels are typically the lowest. Our experiment does not test seasonality in Ulva's response, but our conditions were meant to reflect water conditions in September for Narragansett Bay, one of the months in which Young and Gobler (2016) observed a significant impact of $\mathrm{NO}_{3}{ }^{-}$on Ulva growth.

Increased concentrations of $\mathrm{NH}_{4}{ }^{+}$may be a more significant factor than $\mathrm{NO}_{3}{ }^{-}$. Ulva exhibits an ability to uptake in $\mathrm{NH}_{4}{ }^{+}$as an immediate surge, but ultimately, longer exposure to high levels of $\mathrm{NH}_{4}{ }^{+}$result in reduce uptake (Pederson and Borum, 1997). Rees et al. (2007) showed significantly increased uptake rates of $\mathrm{NH}_{4}{ }^{+}$in Ulva 
intestinalis when $\mathrm{NH}_{4}{ }^{+}$concentrations increased, these uptake rates exceed those for $\mathrm{NO}_{3}{ }^{-}$ , and the increased uptake of $\mathrm{NH}_{4}{ }^{+}$came with reduced uptake of $\mathrm{NO}_{3}{ }^{-}$. Fucus becomes saturated at $\mathrm{NH}_{4}{ }^{+}$and $\mathrm{NO}_{3}{ }^{-}$concentrations around $10-30 \mu \mathrm{M}$ and the maximum uptake rates in this species are less than half of those observed in Ulva (Pederson and Borum, 1997). Fucus, however, spans much of the intertidal and shallow subtidal, and Benes and Bracken (2016) showed greater uptake rates in high shore Fucus. We used Fucus that was found to be submerged at low tide. Fucus found in the lower zone exhibits reduced uptake rates, and in addition, Fucus showed that nitrogen uptake rates are plastic and individuals can adapt rates based on submersion time (Benes and Bracken, 2016). Fucus used in our experiments was not subjected to low tide conditions, and likely adapted to constant submersion. As such, we would expect uptake rates to be reduced even more (Benes and Bracken, 2016).

Our observed Ulva growth rates were also significantly enhanced by the addition of nutrients, similar to prior experimental studies (Steffensen, 1976; Teichberg et al., 2010) and field observations (Díaz et al., 2005), supporting our hypothesis. As a fastgrowing opportunistic species, Ulva can absorb excess nutrients in the water column and form blooms that are detrimental to ecosystems (Teichberg et al., 2010; Valiela et al., 1997) and can lead to eelgrass declines (Hauxwell et al., 2001; McGlathery, 2001). By contrast, we found no effect of nutrient treatment on the growth rate of Fucus. Fucus can take up excess nutrients, but at a marginal rate $(\sim 3 \%)$ that may not enhance growth rates (Savage and Elmgren, 2004). Our analysis, however, did not allow for determining whether $\mathrm{NO}_{3}{ }^{-}$or $\mathrm{NH}_{4}{ }^{+}$played different roles in influencing this increased growth. In addition, while nitrogen has long been thought of as the limiting resource for macroalgae, 
there is evidence that has shown positive correlations between algal growth and phosphorous concentration (Villares et al., 1999). Our nutrient addition included adding phosphorous, but ultimately tissue concentrations of phosphorous were not analyzed and we make no conclusions about the role of phosphorous in macroalgal growth.

Of several studies on the combined impacts of ocean acidification and nutrients (Campbell and Fourqurean, 2014; Falkenberg et al., 2013; Russell et al., 2009), only Russell et al. (2009) found a synergism between these two factors, with turf algal percent cover multiplied when both of these factors are increased. Campbell and Fourquean (2014) and Falkenberg et al. (2013) found that at least one of the factors increased growth rates, but with no significant interaction. Fernández et al. (2017) found that growth and photosynthetic rates of Macrocystis pyrifera were unaffected by $\mathrm{pCO}_{2}$ and despite increased uptake of nitrogen, nutrient conditions were similarly in affective. Comparing field growth and laboratory growth of Ulva, Young and Gobler (2016) found increased $\mathrm{pCO}_{2}$ had a larger impact on growth in Ulva, compared to slight increases in nutrients, but did find evidence that increased nutrients enhances growth (Young and Gobler, 2016) and a few cases where $\mathrm{pCO}_{2}$ and nutrients added synergistically to effect growth rates. Our results do not point to a synergism, but the significant effect of $\mathrm{pCO}_{2}$ and nutrients on Ulva growth we observed supports findings in these studies as we show that growth rates in Ulva were the highest under high $\mathrm{pCO}_{2}$ and high nutrients (Fig. 1A and 1C).

\subsection{Algal Tissue Content}

Overall, we found that increased $\mathrm{pCO}_{2}$ did not affect the C:N ratio of either Ulva spp. or Fucus vesiculosus. Although adding carbon is counterintuitive to decreasing the 
C:N ratio, Gordillo et al. (2001) found that increased $\mathrm{pCO}_{2}$ resulted in increased uptake of nitrate in $U$. rigida, thus lowering the tissue $\mathrm{C}: \mathrm{N}$ ratio. While our results don't show decreased C:N with high $\mathrm{pCO}_{2}$, analysis of Ulva tissues grown in biculture and under high $\mathrm{pCO}_{2}$ show an uptick in nitrogen concentration. Our results, however, indicate that nutrient level was the primary driver of tissue C:N ratio in both Ulva and Fucus, and this may ultimately obscure changes in nitrogen uptake due to increased $\mathrm{pCO}_{2}$. High nutrient treatments resulted in decreased $\mathrm{C}: \mathrm{N}$ ratios, which increases tissue quality. Falkenberg et al. (2013) found that increasing each factor resulted in decreased C:N ratios for turf algae, but only nutrients effectively lowered the $\mathrm{C}: \mathrm{N}$ in the kelp, Ecklonia radiata. We did not find a significant interaction between acidification and nutrients loading on tissue $\mathrm{C}: \mathrm{N}$, similar to Falkenberg et al. (2013). Our results contradict those from Gutow et al. (2014), where high $\mathrm{pCO}_{2}$ resulted in a decreased $\mathrm{C}: \mathrm{N}$ ratio for $F$. vesiculosus.

Our findings indicate that both acidification and nutrients have the ability to alter tissue composition. The addition of $\mathrm{pCO}_{2}$ significantly increased the percent carbon found in Ulva and Fucus tissues, and increased nutrient concentrations raised tissue nitrogen in both. However, $\mathrm{pCO}_{2}$ did not affect the $\mathrm{C}: \mathrm{N}$ rate. Therefore, in our system, nutrients are the key driver of C:N ratios in Ulva and Fucus. While we observed higher concentrations of $\mathrm{N}$ within Ulva tissues grown under high $\mathrm{pCO}_{2}$ treated individuals, the difference was not significant and our results do not match Gordillo et al. (2001) and Xu and Gao (2012), who found that high $\mathrm{pCO}_{2}$ facilitates nitrate uptake in $U$. rigida and $U$. prolifera, respectively.

The uptake of nutrients and carbon is limited by how much of the resource is available per unit biomass. We did not alter the concentrations of nutrients or $\mathrm{pCO}_{2}$ to 
reflect changes in algal biomass between experiments, where biculture experiments had significantly greater algal biomass. However, concentrations of these resources were greater than saturation levels for both algal species, therefore, we do not anticipate that changes in biomass resulted in changes in nutrient uptake and ultimately any changes in tissue $\mathrm{C}$ or $\mathrm{N}$. In addition, there is documented evidence that Ulva allelochemicals harm the growth of Fucus germilings (Nelson et al., 2003), but with high flow rates and balanced algal concentrations, we do not expect these compounds to have played a role in determining the health of Fucus grown in biculture.

\subsection{Monoculture vs. Biculture:}

Our experimental design and execution was impacted by the seasonality of Ulva in Narragansett Bay. As such, experiments were designed and planned in effort to utilize current growing seasons of both macroalgal species. This limited our ability to simultaneously run monocultures and bicultures. However, as this study was done under laboratory conditions, we had the ability to control and maintain environmental parameters throughout. Comparisons can be made between monoculture and biculture experiments, but arguments about the impact of one algal species on another could be bolstered by a more randomized experimental design. While we observed almost identical growth rates of both Ulva and Fucus between monoculture and biculture experiments, we did find an effect of Ulva on Fucus as evidence of altered C:N ratios of Fucus in biculture experiments, where C: $\mathrm{N}$ of Fucus was significantly higher in tissues when grown with Ulva. This is potentially due to the inability of Fucus to acquire nutrients in the presence of fast-growing, nutrient limited species like Ulva (Duarte, 
1995). While growth rates of either species seemed unaffected by culture, finding changes in tissue composition and ultimately access to nutrients as a result of biculture may point to longer-term impacts of one species on another. Experimental duration and within tank algal densities likely played a role in masking any tangible effects of one species on another in terms of growth rates. Alestra and Schiel, 2015 tracked fucoid growth under different environmental and culture conditions (also using Ulva) over a 6 week period, and while they observed decreased size in fucoid germlings grown alongside Ulva, the percent cover of Ulva didn't start significantly expanding until 4-6 weeks into the experiment. At 21 days, our experiment might not have allowed for enough time to observe size discrepancies between Fucus grown in monoculture and in biculture.

Interspecific competition and interactions for space and resources drive algal community composition and function (Olson and Lubchenco, 1990; Stachowicz, 2001), and algal communities may undergo assemblage shifts under climate change (Connell and Russell, 2010). However, to more completely understand the interactions between algal species (and ultimately any competitive effects) we would need to expose algal species to the same environmental treatments using a replacement-additive design. As

such, while we found evidence of Ulva affecting Fucus, we cannot say with confidence that this is evidence of resource competition.

\subsection{Impacts to Coastal Ecosystems}

In coastal systems where anthropogenic nutrient loading is prevalent, algal blooms are likely occur. The role of nutrients in facilitating macroalgal blooms is well 
established (Lapointe, 1997; Lapointe and Bedford, 2010). While both nutrients and $\mathrm{CO}_{2}$ are both resources for primary producers, few studies have assessed the role of $\mathrm{pCO}_{2}$ in contributing to blooms. As our study shows, increased nutrients and $\mathrm{pCO}_{2}$ result in faster Ulva growth, and their combination results in the largest RGR. Quantifying this effect may allow for better prediction of opportunistic and bloom forming macroalgal response to common coastal environmental stressors. As such, ocean acidification may ultimately end up contributing to the timing, frequency, and duration of macroalgal blooms. Ocean acidification has been shown to not only enhance growth rates in some algal species but also may enhance the uptake of nutrients (Gordillo et al., 2001), increasing growth rates indirectly. In addition, acidification can alleviate the cold-driven temperature stress in a species of red algae, resulting in higher growth rates in colder waters (Olischläger and Wiencke, 2013).

Seaweed takeover of critical ecosystems such as coral reefs (Diaz-Pulido et al., 2011) and the turf algal dominance in kelp forest ecosystems (Connell and Russell, 2010) highlight the prediction that many macroalgal species are expected to flourish under future climate scenarios. Field studies of algal diversity at naturally low $\mathrm{pH}$ vent sites indicate shifting assemblages as water become more acidic (Porzio et al., 2011). Our results highlight the ability of fast-growing, ephemeral species to take advantage of changing conditions. In other systems, these fast-growing species are predicted to outcompete larger, slow-growing species (Connell and Russell, 2010; Falkenberg et al., 2013). While long-lived species like Fucus may not be directly impacted by environmental change as our results show, they may, however be indirectly affected by the overgrowth of epiphytes (Berger et al., 2004) or competing species. Fucus dominates 
space in the intertidal and shallow subtidal and helps create complex, 3-D structure that is critically important as a source of refuge and habitat for other organisms in the community. Our results do not describe a direct, negative effect of acidification or nutrients on Fucus, but these indirect effects may ultimately result in Fucus decline, altering algal community assemblages and ecosystem services. As Ulva is a seasonal macroalga, a takeover of Fucus, or other perennial species is not likely, but as Olischläger and Wiencke (2013) showed an ability for increased $\mathrm{pCO}_{2}$ to alleviate cold temperature stress, the growing season of Ulva may be extended, which could have implications for perennial species.

While results from our study highlight the divergent responses of two macroalgal species to climate and environmental change, we only tested these species at one density, an important caveat when putting context to the results of our biculture study. Although our densities were within the range of ecological relevance, seasonal changes in recruitment, growth, and density will likely play a role in shaping community response to climate change. Seaweed density has long been known as an important factor in determining the settlement and success of other species within a community (Schiel 1985, Ansell et al., 1998). We showed that increases in $\mathrm{pCO}_{2}$ and nutrients can significantly enhance Ulva growth rates, and that Ulva presence and success appears to have a quantifiable impact on other macroalgae potentially impacting the timing, duration, and size of macroalgal blooms. The design of this study, however, did not allow for determining how different densities of certain species play a role in community dynamics. Blooms of green alga, like Ulva, can have a profound impact on the survival of other macroalgae and in some instances have resulted in the decline and replacement of 
coinhabitants (Valiela et al., 1997). To better understand the dynamics of change in macroalgal communities in context of climate change, studies investigating different densities are needed. In addition, to fully quantify how macroalgal communities will respond to change more work needs to be done investigating how larger, more diverse communities respond. It is necessary to quantify algal community response over long periods of time, as the seasonality of algal species in temperate coastal ecosystems will likely play a role in determining community dynamics.

\section{Acknowledgements}

This research has been supported by a grant from the U.S. Environmental Protection Agency's Science to Achieve Results (STAR) program. This material is based upon work supported in part by the National Science Foundation EPSCoR Cooperative Agreement \#EPS-1004057. We thank J Grear and the US EPA Atlantic Ecology Division for support and aide in experimental set up and design, and A Pimenta for laboratory assistance.

\section{References}

Aldridge, J.N., Trimmer, M., 2009. Modelling the distribution and growth of "problem"green seaweed in the Medway estuary, UK, in: Eutrophication in Coastal Ecosystems. Springer, pp. 107-122.

Alestra, T., Schiel, D.R., 2015. Non-trophic responses of algal communities to nutrient enrichment: interactions among coralline turfs, ephemeral algae and perennial fucoids. Marine Ecology Progress Series 538, 145-156.

Anderson, D.M., Glibert, P.M., Burkholder, J.M., 2002. Harmful algal blooms and eutrophication: Nutrient sources, composition, and consequences. Estuaries 25, 704-726. doi:10.1007/BF02804901

Axelsson, L., Larsson, C., Ryberg, H., 1999. Affinity, capacity and oxygen sensitivity of two different mechanisms for bicarbonate utilization in Ulva lactuca L.(Chlorophyta). Plant, Cell \& Environment 22, 969-978. 
Axelsson, L., Mercado, J.M., Figueroa, F.L., 2000. Utilization of $\mathrm{HCO}_{3}{ }^{-}$at high $\mathrm{pH}$ by the brown macroalga Laminaria saccharina. European Journal of Phycology 35, 53-59.

Axelsson, L., Ryberg, H., Beer, S., 1995. Two modes of bicarbonate utilization in the marine green macroalga Ulva lactuca. Plant, Cell \& Environment 18, 439-445.

Bäck, S., Ruuskanen, A., 2000. Distribution and maximum growth depth of Fucus vesiculosus along the Gulf of Finland. Marine Biology 136, 303-307. doi: $10.1007 / \mathrm{s} 002270050688$

Benes, K.M., Bracken, M.E.S., 2016. Nitrate uptake varies with tide height and nutrient availability in the intertidal seaweed Fucus vesiculosus. J. Phycol. 52, 863-876. doi:10.1111/jpy.12454

Berger, R., Bergström, L., Granéli, E., Kautsky, L., 2004. How does eutrophication affect different life stages of Fucus vesiculosus in the Baltic Sea? A conceptual model. Hydrobiologia 514, 243-248.

Bracken, M.E.S., Dolecal, R.E., Long, J.D., 2014. Community context mediates the topdown vs. bottom-up effects of grazers on rocky shores. Ecology 95, 1458-1463. doi:10.1890/13-2094.1

Cai, W.-J., Hu, X., Huang, W.-J., Murrell, M.C., Lehrter, J.C., Lohrenz, S.E., Chou, W.C., Zhai, W., Hollibaugh, J.T., Wang, Y., Zhao, P., Guo, X., Gundersen, K., Dai, M., Gong, G.-C., 2011. Acidification of subsurface coastal waters enhanced by eutrophication. Nature Geoscience 4, 766-770. doi:10.1038/ngeo1297

Campbell, J.E., Fourqurean, J.W., 2014. Ocean acidification outweighs nutrient effects in structuring seagrass epiphyte communities. Journal of Ecology 102, 730-737. doi:10.1111/1365-2745.12233

Comeau, S., Edmunds, P.J., Spindel, N.B., Carpenter, R.C., 2014. Fast coral reef calcifiers are more sensitive to ocean acidification in short-term laboratory incubations. Limnology and Oceanography 59, 1081-1091.

Connell, S.D., Russell, B.D., 2010. The direct effects of increasing $\mathrm{CO}_{2}$ and temperature on non-calcifying organisms: increasing the potential for phase shifts in kelp forests. Proceedings of the Royal Society of London B: Biological Sciences rspb20092069.

Cornwall, C.E., Hepburn, C.D., Pritchard, D., Currie, K.I., McGraw, C.M., Hunter, K.A., Hurd, C.L., 2012. Carbon-use strategies in macroalgae: differential responses to lowered $\mathrm{pH}$ and implications for ocean acidification1. Journal of Phycology 48, $137-144$.

Coutinho, R., Zingmark, R., 1993. Interactions of light and nitrogen on photosynthesis and growth of the marine macroalga Ulva curvata (Kützing) De Toni. Journal of Experimental Marine Biology and Ecology 167, 11-19.

Creed, J.C., Norton, T.A., Kain (Jones), J.M., 1996. Are neighbours harmful or helpful in Fucus vesiculosus populations? Marine Ecology Progress Series 133, 191-201. doi: $10.2307 / 24856119$

Díaz, P., Gappa, J.J.L., Piriz, M.L., 2005. Symptoms of Eutrophication in Intertidal Macroalgal Assemblages of Nuevo Gulf (Patagonia, Argentina). Botanica Marina 45, 267-273. doi:10.1515/BOT.2002.026 
Diaz-Pulido, G., Gouezo, M., Tilbrook, B., Dove, S., Anthony, K., 2011. High $\mathrm{CO}_{2}$ enhances the competitive strength of seaweeds over corals. Ecology Letters 14, $156-162$.

Dickson, A.G., Sabine, C.L., Christian, J.R., others, 2007. Guide to best practices for ocean $\mathrm{CO}_{2}$ measurements.

Duarte, C.M., 1995. Submerged aquatic vegetation in relation to different nutrient regimes. Ophelia 41, 87-112. doi:10.1080/00785236.1995.10422039

Falkenberg, L.J., Russell, B.D., Connell, S.D., 2013. Contrasting resource limitations of marine primary producers: implications for competitive interactions under enriched $\mathrm{CO}_{2}$ and nutrient regimes. Oecologia 172, 575-583.

Fernández, P.A., Roleda, M.Y., Hurd, C.L., 2015. Effects of ocean acidification on the photosynthetic performance, carbonic anhydrase activity and growth of the giant kelp Macrocystis pyrifera. Photosynthesis Research 124, 293-304. doi:10.1007/s11120-015-0138-5

Fernández, P.A., Roleda, M.Y., Leal, P.P., Hepburn, C.D., Hurd, C.L., 2017. Tissue nitrogen status does not alter the physiological responses of Macrocystis pyrifera to ocean acidification. Marine Biology 164, 177. doi:10.1007/s00227-017-3204-z

Frommel, A.Y., Margulies, D., Wexler, J.B., Stein, M.S., Scholey, V.P., Williamson, J.E., Bromhead, D., Nicol, S., Havenhand, J., 2016. Ocean acidification has lethal and sub-lethal effects on larval development of yellowfin tuna, Thunnus albacares. Journal of Experimental Marine Biology and Ecology 482, 18-24. doi:10.1016/j.jembe.2016.04.008

Gaitán-Espitia, J.D., Hancock, J.R., Padilla-Gamiño, J.L., Rivest, E.B., Blanchette, C.A., Reed, D.C., Hofmann, G.E., 2014. Interactive effects of elevated temperature and $\mathrm{pCO}_{2}$ on early-life-history stages of the giant kelp Macrocystis pyrifera. Journal of Experimental Marine Biology and Ecology 457, 51-58. doi:10.1016/j.jembe.2014.03.018

Giordano, M., Beardall, J., Raven, J.A., 2005. $\mathrm{CO}_{2}$ concentrating mechanisms in algae: mechanisms, environmental modulation, and evolution. Annual Reviews in Plant Biology 56, 99-131.

Gordillo, F.J., Niell, F.X., Figueroa, F.L., 2001. Non-photosynthetic enhancement of growth by high $\mathrm{CO}_{2}$ level in the nitrophilic seaweed Ulva rigida $\mathrm{C}$. Agardh (Chlorophyta). Planta 213, 64-70.

Granger, S., Brush, M.J., Buckley, B.A., Schwartz, M.L., 2000. An assessment of eutrophication in Greenwich Bay. Citeseer.

Guidone, M., Thornber, C., Wysor, B., O’Kelly, C.J., 2013. Molecular and morphological diversity of Narragansett Bay (RI, USA) Ulva (Ulvales, Chlorophyta) populations. Journal of Phycology. 49, 979-995. doi:10.1111/jpy.12108

Gutow, L., Rahman, M.M., Bartl, K., Saborowski, R., Bartsch, I., Wiencke, C., 2014. Ocean acidification affects growth but not nutritional quality of the seaweed Fucus vesiculosus (Phaeophyceae, Fucales). Journal of Experimental Marine Biology and Ecology 453, 84-90.

Harley, C.D., Randall Hughes, A., Hultgren, K.M., Miner, B.G., Sorte, C.J., Thornber, C.S., Rodriguez, L.F., Tomanek, L., Williams, S.L., 2006. The impacts of climate change in coastal marine systems. Ecology letters 9, 228-241. 
Hauxwell, J., Cebrián, J., Furlong, C., Valiela, I., 2001. Macroalgal canopies contribute to eelgrass (Zostera marina) decline in temperate estuarine ecosystems. Ecology 82, 1007-1022.

Hemmi, A., Mäkinen, A., Jormalainen, V., Honkanen, T., 2005. Responses of growth and phlorotannins in Fucus vesiculosus to nutrient enrichment and herbivory. Aquatic Ecology 39, 201-211. doi:10.1007/s10452-004-3526-z

Hepburn, C.D., Pritchard, D.W., Cornwall, C.E., McLeod, R.J., Beardall, J., Raven, J.A., Hurd, C.L., 2011. Diversity of carbon use strategies in a kelp forest community: implications for a high $\mathrm{CO}_{2}$ ocean. Global Change Biology 17, 2488-2497.

Hoegh-Guldberg, O., Mumby, P.J., Hooten, A.J., Steneck, R.S., Greenfield, P., Gomez, E., Harvell, C.D., Sale, P.F., Edwards, A.J., Caldeira, K., others, 2007. Coral reefs under rapid climate change and ocean acidification. science 318, 1737-1742.

Hofmann, G.E., Smith, J.E., Johnson, K.S., Send, U., Levin, L.A., Micheli, F., Paytan, A., Price, N.N., Peterson, B., Takeshita, Y., others, 2011. High-frequency dynamics of ocean $\mathrm{pH}$ : a multi-ecosystem comparison. PloS one 6, e28983.

Hofmann, L.C., Nettleton, J.C., Neefus, C.D., Mathieson, A.C., 2010. Cryptic diversity of Ulva (Ulvales, Chlorophyta) in the Great Bay Estuarine System (Atlantic USA): introduced and indigenous distromatic species. European Journal of Phycology 45, 230-239. doi:10.1080/09670261003746201

Israel, A., Hophy, M., 2002. Growth, photosynthetic properties and Rubisco activities and amounts of marine macroalgae grown under current and elevated seawater $\mathrm{CO}_{2}$ concentrations. Global Change Biology 8, 831-840.

Kawamitsu, Y., Boyer, J.S., 1999. Photosynthesis and carbon storage between tides in a brown alga, Fucus vesiculosus. Marine Biology 133, 361-369.

Koch, M., Bowes, G., Ross, C., Zhang, X.-H., 2013. Climate change and ocean acidification effects on seagrasses and marine macroalgae. Global Change Biology 19, 103-132.

Kroeker, K.J., Kordas, R.L., Crim, R., Hendriks, I.E., Ramajo, L., Singh, G.S., Duarte, C.M., Gattuso, J.P., 2013. Impacts of ocean acidification on marine organisms: quantifying sensitivities and interaction with warming. Global Change Biology 19, 1884-1896. doi:10.1111/gcb.12179

Kroeker, K.J., Kordas, R.L., Crim, R.N., Singh, G.G., 2010. Meta-analysis reveals negative yet variable effects of ocean acidification on marine organisms. Ecology letters 13, 1419-1434.

Krumholz, J.S., 2012. Spatial and temporal patterns in nutrient standing stock and massbalance in response to load reductions in a temperate estuary. Dissertations and Master's Theses (Campus Access) 1-400.

Kübler, J.E., Johnston, A.M., Raven, J.A., 1999. The effects of reduced and elevated $\mathrm{CO}_{2}$ and $\mathrm{O} 2$ on the seaweed Lomentaria articulata. Plant, Cell \& Environment 22, $1303-1310$.

Lapointe, B.E., 1997. Nutrient thresholds for bottom-up control of macroalgal blooms on coral reefs in Jamaica and southeast Florida. Limnology and Oceanography 42, 1119-1131.

Lapointe, B.E., Bedford, B.J., 2010. Ecology and nutrition of invasive Caulerpa brachypus f. parvifolia blooms on coral reefs off southeast Florida, USA. Harmful Algae 9, 1-12. 
Lee, V., Olsen, S., 1985. Eutrophication and management initiatives for the control of nutrient inputs to Rhode Island coastal lagoons. Estuaries 8, 191-202.

Lubchenco, J., 1983. Littorina and Fucus: Effects of Herbivores, Substratum Heterogeneity, and Plant Escapes During Succession. Ecology 64, 1116-1123. doi: $10.2307 / 1937822$

McGlathery, K.J., 2001. Macroalgal blooms contribute to the decline of seagrass in nutrient-enriched coastal waters. Journal of Phycology 37, 453-456.

Mehrbach, C., Culberson, C.H., Hawley, J.E., Pytkowicx, R.M., 1973. Measurement of the Apparent Dissociation Constants of Carbonic Acid in Seawater at Atmospheric Pressure. Limnology and Oceanography. 18, 897-907. doi:10.4319/1o.1973.18.6.0897

Mercado, J.M., Gordillo, F.J.L., 2011. Inorganic carbon acquisition in algal communities: are the laboratory data relevant to the natural ecosystems? Photosynthesis Research 109, 257-267.

Moss, B., 1967. The Apical Meristem of Fucus. New Phytologist 66, 67-74. doi:10.1111/j.1469-8137.1967.tb05988.x

Moss, R.H., Edmonds, J.A., Hibbard, K.A., Manning, M.R., Rose, S.K., Van Vuuren, D.P., Carter, T.R., Emori, S., Kainuma, M., Kram, T., others, 2010. The next generation of scenarios for climate change research and assessment. Nature 463, 747-756.

Moulin, P., Andría, J.R., Axelsson, L., Mercado, J.M., 2011. Different mechanisms of inorganic carbon acquisition in red macroalgae (Rhodophyta) revealed by the use of TRIS buffer. Aquatic Botany 95, 31-38. doi:10.1016/j.aquabot.2011.03.007

Munday, P.L., Dixson, D.L., Donelson, J.M., Jones, G.P., Pratchett, M.S., Devitsina, G.V., Døving, K.B., 2009. Ocean acidification impairs olfactory discrimination and homing ability of a marine fish. PNAS 106, 1848-1852. doi:10.1073/pnas.0809996106

Nelson, T.A., Lee, D.J., Smith, B.C., 2003. Are “Green Tides” Harmful Algal Blooms? Toxic Properties of Water-Soluble Extracts from Two Bloom-Forming Macroalgae, Ulva Fenestrata and Ulvaria Obscura (ulvophyceae). Journal of Phycology 39, 874-879. doi:10.1046/j.1529-8817.2003.02157.x

Neori, A., Cohen, I., Gordin, H., 1991. Ulva lactuca biofilters for marine fishpond effluents. II. Growth rate, yield and C: N ratio. Botanica Marina 34, 483-490.

Nixon, S.W., 1995. Coastal marine eutrophication: a definition, social causes, and future concerns. Ophelia 41, 199-219.

Olischläger, M., Bartsch, I., Gutow, L., Wiencke, C., 2013. Effects of ocean acidification on growth and physiology of Ulva lactuca (Chlorophyta) in a rockpool-scenario. Phycological Research 61, 180-190.

Olischläger, M., Bartsch, I., Gutow, L., Wiencke, C., 2012. Effects of ocean acidification on different life-cycle stages of the kelp Laminaria hyperborea (Phaeophyceae). Botanica Marina 55, 511-525. doi:10.1515/bot-2012-0163

Olischläger, M., Wiencke, C., 2013. Ocean acidification alleviates low-temperature effects on growth and photosynthesis of the red alga Neosiphonia harveyi (Rhodophyta). J. Exp. Bot. 64, 5587-5597. doi:10.1093/jxb/ert329

Olson, A.M., Lubchenco, J., 1990. Competition in seaweeds: linking plant traits to competitive outcomes. Journal of Phycology 26, 1-6. 
Pachauri, R.K., Allen, M.R., Barros, V.R., Broome, J., Cramer, W., Christ, R., Church, J.A., Clarke, L., Dahe, Q., Dasgupta, P., Dubash, N.K., Edenhofer, O., Elgizouli, I., Field, C.B., Forster, P., Friedlingstein, P., Fuglestvedt, J., Gomez-Echeverri, L., Hallegatte, S., Hegerl, G., Howden, M., Jiang, K., Jimenez Cisneroz, B., Kattsov, V., Lee, H., Mach, K.J., Marotzke, J., Mastrandrea, M.D., Meyer, L., Minx, J., Mulugetta, Y., O’Brien, K., Oppenheimer, M., Pereira, J.J., Pichs-Madruga, R., Plattner, G.-K., Pörtner, H.-O., Power, S.B., Preston, B., Ravindranath, N.H., Reisinger, A., Riahi, K., Rusticucci, M., Scholes, R., Seyboth, K., Sokona, Y., Stavins, R., Stocker, T.F., Tschakert, P., van Vuuren, D., van Ypserle, J.-P., 2014. Climate Change 2014: Synthesis Report. Contribution of Working Groups I, II and III to the Fifth Assessment Report of the Intergovernmental Panel on Climate Change. IPCC, Geneva, Switzerland.

Pedersen, M.F., Borum, J., 1996. Nutrient control of algal growth in estuarine waters. Nutrient limitation and the importance of nitrogen requirements and nitrogen storage among phytoplankton and species of macroalgae. Marine ecology progress series. Oldendorf 142, 261-272.

Pederson, M.F., Borum, J., 1997. Nutrient control of estuarine macroalgae: growth strategy and the balance between nitrogen requirements and uptake. Marine Ecology Progress Series 155-163.

Pierrot, D., Lewis, E., \& Wallace, D. W. R., 2006. CO2SYS DOS Program developed for $\mathrm{CO}_{2}$ system calculations. ORNL/CDIAC-105. Carbon Dioxide Information Analysis Center, Oak Ridge National Laboratory, US Department of Energy, Oak Ridge, TN. Porzio, L., Buia, M.C., Hall-Spencer, J.M., 2011. Effects of ocean acidification on macroalgal communities. Journal of Experimental Marine Biology and Ecology 400, 278-287.

Rautenberger, R., Fernández, P.A., Strittmatter, M., Heesch, S., Cornwall, C.E., Hurd, C.L., Roleda, M.Y., 2015. Saturating light and not increased carbon dioxide under ocean acidification drives photosynthesis and growth in Ulva rigida (Chlorophyta). Ecol Evol 5, 874-888. doi:10.1002/ece3.1382

Raven, J.A., Beardall, J., 2003. Carbon acquisition mechanisms of algae: carbon dioxide diffusion and carbon dioxide concentrating mechanisms, in: Photosynthesis in Algae. Springer, pp. 225-244.

Rees, T. a. V., Dobson, B.C., Bijl, M., Morelissen, B., 2007. Kinetics of nitrate uptake by New Zealand marine macroalgae and evidence for two nitrate transporters in Ulva intestinalis L. Hydrobiologia 586, 135-141. doi:10.1007/s10750-006-0569-2

Ries, J.B., Cohen, A.L., McCorkle, D.C., 2009. Marine calcifiers exhibit mixed responses to $\mathrm{CO}_{2}$-induced ocean acidification. Geology 37, 1131-1134.

Rohde, S., Hiebenthal, C., Wahl, M., Karez, R., Bischof, K., 2008. Decreased depth distribution of Fucus vesiculosus (Phaeophyceae) in the Western Baltic: effects of light deficiency and epibionts on growth and photosynthesis. European Journal of Phycology 43, 143-150. doi:10.1080/09670260801901018

Roleda, M.Y., Cornwall, C.E., Feng, Y., McGraw, C.M., Smith, A.M., Hurd, C.L., 2015. Effect of Ocean Acidification and $\mathrm{pH}$ Fluctuations on the Growth and Development of Coralline Algal Recruits, and an Associated Benthic Algal Assemblage. PLOS ONE 10, e0140394. doi:10.1371/journal.pone.0140394 
Roleda, M.Y., Morris, J.N., McGraw, C.M., Hurd, C.L., 2012. Ocean acidification and seaweed reproduction: increased $\mathrm{CO} 2$ ameliorates the negative effect of lowered $\mathrm{pH}$ on meiospore germination in the giant kelp Macrocystis pyrifera (Laminariales, Phaeophyceae). Global Change Biology 18, 854-864.

Russell, B.D., Thompson, J.-A.I., Falkenberg, L.J., Connell, S.D., 2009. Synergistic effects of climate change and local stressors: $\mathrm{CO}_{2}$ and nutrient-driven change in subtidal rocky habitats. Global Change Biology 15, 2153-2162.

Sarker, M.Y., Bartsch, I., Olischläger, M., Gutow, L., Wiencke, C., 2013. Combined effects of $\mathrm{CO}_{2}$, temperature, irradiance and time on the physiological performance of Chondrus crispus (Rhodophyta). Botanica Marina 56, 63-74.

Savage, C., Elmgren, R., 2004. Macroalgal (Fucus vesiculosus) $\delta 15 \mathrm{~N}$ values trace decrease in sewage influence. Ecological Applications 14, 517-526.

Stachowicz, J.J., 2001. Mutualism, Facilitation, and the Structure of Ecological Communities Positive interactions play a critical, but underappreciated, role in ecological communities by reducing physical or biotic stresses in existing habitats and by creating new habitats on which many species depend. Bioscience 51, 235246.

Steffensen, D.A., 1976. The effect of nutrient enrichment and temperature on the growth in culture of Ulva lactuca L. Aquatic Botany 2, 337-351. doi:10.1016/03043770(76)90031-0

Swanson, A.K., Fox, C.H., 2007. Altered kelp (Laminariales) phlorotannins and growth under elevated carbon dioxide and ultraviolet-B treatments can influence associated intertidal food webs. Global Change Biology 13, 1696-1709.

Tate, C.M., 1990. Patterns and Controls of Nitrogen in Tallgrass Prairie Streams. Ecology 71, 2007-2018. doi:10.2307/1937609

Teichberg, M., Fox, S.E., Olsen, Y.S., Valiela, I., Martinetto, P., Iribarne, O., Muto, E.Y., Petti, M.A., Corbisier, T.N., Soto-Jiménez, M., others, 2010. Eutrophication and macroalgal blooms in temperate and tropical coastal waters: nutrient enrichment experiments with Ulva spp. Global Change Biology 16, 2624-2637.

Thomsen, M.S., McGlathery, K.J., Tyler, A.C., 2006. Macroalgal distribution patterns in a shallow, soft-bottom lagoon, with emphasis on the nonnative Gracilaria vermiculophylla and Codium fragile. Estuaries and Coasts: J ERF 29, 465-473. doi:10.1007/BF02784994

Thornber, C.S., DiMilla, P., Nixon, S.W., McKinney, R.A., 2008. Natural and anthropogenic nitrogen uptake by bloom-forming macroalgae. Marine Pollution Bulletin 56, 261-269.

Turner, C., 2015. Verification of pH fluctuations in Narragansett Bay. Dissertations and Master's Theses (Campus Access) 1-119.

Valiela, I., McClelland, J., Hauxwell, J., Behr, P.J., Hersh, D., Foreman, K., 1997. Macroalgal blooms in shallow estuaries: controls and ecophysiological and ecosystem consequences. Limnology and oceanography 42, 1105-1118.

Villares, R., Puente, X., \& Carballeira, A., 1999. Nitrogen and phosphorus in Ulva sp. in the Galician Rias Bajas (northwest Spain): seasonal fluctuations and influence on growth. Boletin-Instituto Espanol De Oceanografia, 15(1/4), 337-342. 
Waldbusser, G.G., Hales, B., Langdon, C.J., Haley, B.A., Schrader, P., Brunner, E.L., Gray, M.W., Miller, C.A., Gimenez, I., 2015. Saturation-state sensitivity of marine bivalve larvae to ocean acidification. Nature Climate Change 5, 273-280.

Watson, D.C., Norton, T.A., 1985. Dietary preferences of the common periwinkle, Littorina littorea (L.). Journal of Experimental Marine Biology and Ecology 88, 193-211. doi:10.1016/0022-0981(85)90230-8

Worm, B., Lotze, H.K., 2006. Effects of eutrophication, grazing, and algal blooms on rocky shores. Limnology Oceanography 51, 569-579. doi:10.4319/lo.2006.51.1_part_2.0569

$\mathrm{Xu}, \mathrm{J}$. , Gao, K., 2012. Future $\mathrm{CO}_{2}$-induced ocean acidification mediates the physiological performance of a green tide alga. Plant physiology 160, 1762-1769.

Young, C.S., Gobler, C.J., 2016. Ocean Acidification Accelerates the Growth of Two Bloom-Forming Macroalgae. PLOS ONE 11, e0155152. doi:10.1371/journal.pone.0155152

Zimmerman, R.C., Kohrs, D.G., Steller, D.L., Alberte, R.S., 1997. Impacts of $\mathrm{CO}_{2}$ enrichment on productivity and light requirements of eelgrass. Plant Physiology $115,599-607$.

Zou, D., 2005. Effects of elevated atmospheric $\mathrm{CO}_{2}$ on growth, photosynthesis and nitrogen metabolism in the economic brown seaweed, Hizikia fusiforme (Sargassaceae, Phaeophyta). Aquaculture 250, 726-735.

doi:10.1016/j.aquaculture.2005.05.014 
Table 1. Carbonate chemistry and nutrient parameters averaged across all experiments. Water samples were collected at four times over a two day period in each experiment, resulting in four water samples per treatment per week. Dissolved inorganic carbon (DIC), total alkalinity (TA), temperature, and salinity were measured directly. CO2SYS (Pierrot et al. 2006) was used to calculate $\mathrm{pH}, \mathrm{pCO}_{2}, \mathrm{CO}_{2}, \mathrm{HCO}_{3}{ }^{-}$, and $\mathrm{CO}_{3}{ }^{2-}$. Nitrate $\left(\mathrm{NO}_{3}{ }^{-}\right)$, Ammonium $\left(\mathrm{NH}_{4}{ }^{+}\right)$and phosphate $\left(\mathrm{PO}_{4}{ }^{3-}\right)$ were measured from water samples that were taken weekly over the course of experimentation. All values represent means \pm standard error.

\begin{tabular}{|c|c|c|c|c|}
\hline & \multicolumn{2}{|c|}{ Ambient pCO } & \multicolumn{2}{|c|}{ High $\mathrm{pCO}_{2}$} \\
\hline PARAMETER & $\begin{array}{l}\text { Ambient } \\
\text { Nutrients }\end{array}$ & High Nutrients & $\begin{array}{l}\text { Ambient } \\
\text { Nutrients }\end{array}$ & High Nutrients \\
\hline $\mathrm{pH}$ & $7.96 \pm 0.02$ & $7.97 \pm 0.06$ & $7.62 \pm 0.02$ & $7.62 \pm 0.04$ \\
\hline $\mathrm{pCO}_{2}(\mu \mathrm{atm})$ & $469.27 \pm 19$ & $459.58 \pm 15$ & $1119.07 \pm 60$ & $1134.82+99$ \\
\hline $\begin{array}{l}\mathrm{CO}_{2} \\
(\mu \mathrm{mol} / \mathrm{kgSW})\end{array}$ & $16.36 \pm 0.7$ & $16.03 \pm 0.5$ & $39.25 \pm 2.0$ & $39.73 \pm 4.0$ \\
\hline $\begin{array}{l}\mathrm{HCO}_{3}^{-} \\
(\mu \mathrm{mol} / \mathrm{kgSW})\end{array}$ & $1808.3 \pm 11$ & $1802.7 \pm 7.0$ & $1964.2 \pm 14$ & $1959.9 \pm 10$ \\
\hline $\begin{array}{l}\mathrm{CO}_{3}^{2-} \\
(\mu \mathrm{mol} / \mathrm{kgSW})\end{array}$ & $128.03 \pm 4.5$ & $129.80 \pm 8.0$ & $62.78 \pm 3.3$ & $62.13 \pm 5.7$ \\
\hline $\begin{array}{l}\text { DIC } \\
(\mu \mathrm{mol} / \mathrm{kgSW})\end{array}$ & $1952.7 \pm 10$ & $1948.7 \pm 6.9$ & $2066.0 \pm 15$ & $2062.0 \pm 11$ \\
\hline $\begin{array}{l}\text { TA } \\
(\mu \mathrm{mol} / \mathrm{kgSW})\end{array}$ & $2126.6 \pm 12$ & $2125.1 \pm 10$ & $2120.3 \pm 16$ & $2114.4 \pm 19$ \\
\hline Temp. $\left({ }^{\circ} \mathrm{C}\right)$ & $18.1 \pm 0.07$ & $18.07 \pm 0.04$ & $17.96 \pm 0.05$ & $17.98 \pm 0.05$ \\
\hline Salinity (ppt) & $30.8 \pm 0.02$ & $30.8 \pm 0.02$ & $30.7 \pm 0.02$ & $30.7 \pm 0.03$ \\
\hline $\mathrm{NO}_{3}^{-}(\mu \mathrm{M})$ & $3.40 \pm 1.5$ & $84.78 \pm 2.3$ & $3.32 \pm 1.5$ & $88.15 \pm 5.2$ \\
\hline $\mathrm{NH}_{4}^{+}(\mu \mathrm{M})$ & $5.65 \pm 0.56$ & $88.34 \pm 2.1$ & $5.22 \pm 0.46$ & $92.08 \pm 4.7$ \\
\hline $\mathrm{PO}_{4}{ }^{3-}(\mu \mathrm{M})$ & $1.68 \pm 0.2$ & $3.68 \pm 0.9$ & $1.49 \pm 0.3$ & $3.97 \pm 1.7$ \\
\hline
\end{tabular}


Table 2. Summary of two-way ANOVAS showing the effects of ocean acidification $\left(\mathrm{pCO}_{2}\right)$ and nutrient addition (Nutrients) and their interactions on the growth rates (RGR $\% \mathrm{~g}^{-1}$ ) of $U l v a$ and Fucus grown in monoculture (a) and biculture (b). P-values that are significant $(\mathrm{P} \leq 0.05)$ are in bold.

\begin{tabular}{|c|c|c|c|c|c|c|c|c|}
\hline \multirow[b]{2}{*}{ Model Source } & \multicolumn{4}{|c|}{ Ulva } & \multicolumn{4}{|c|}{ Fucus } \\
\hline & df & SS & $F$ & $\mathrm{P}$ & $\mathrm{df}$ & SS & $\mathrm{F}$ & $\mathrm{P}$ \\
\hline \multicolumn{9}{|l|}{ RGR (\%g day $\left.{ }^{-1}\right)$} \\
\hline$p \mathrm{CO}_{2}$ & 1 & 24.61 & 10.06 & 0.005 & 1 & 0.10 & 0.47 & 0.50 \\
\hline Nutrients & 1 & 33.92 & 13.87 & 0.002 & 1 & 0.09 & 0.43 & 0.52 \\
\hline$p \mathrm{CO}_{2} X$ & 1 & 0.11 & 0.04 & 0.84 & 1 & 0.12 & 0.60 & 0.45 \\
\hline \multicolumn{9}{|l|}{ Nutrients } \\
\hline Error & 18 & 44.01 & & & 24 & 4.92 & & \\
\hline
\end{tabular}

b.

\begin{tabular}{|c|c|c|c|c|c|c|c|c|}
\hline & \multicolumn{4}{|c|}{ Ulva } & \multicolumn{4}{|c|}{ Fucus } \\
\hline Model Source & df & SS & $F$ & $\mathrm{P}$ & $\mathrm{df}$ & SS & $\mathrm{F}$ & $\mathrm{P}$ \\
\hline RGR (\%g day $\left.{ }^{-1}\right)$ & & & & & & & & \\
\hline$p \mathrm{CO}_{2}$ & 1 & 25.60 & 7.71 & 0.012 & 1 & 0.001 & 0.01 & 0.92 \\
\hline Nutrients & 1 & 53.85 & 16.23 & 0.001 & 1 & 0.08 & 0.62 & 0.44 \\
\hline$p \mathrm{CO}_{2} X$ & 1 & 1.41 & 0.42 & 0.52 & 1 & 0.04 & 0.31 & 0.58 \\
\hline Nutrients & & & & & & & & \\
\hline Error & 18 & 59.73 & & & 24 & 3.22 & & \\
\hline
\end{tabular}


Table 3. Summary of two-way ANOVAS showing the effects of ocean acidification $\left(\mathrm{pCO}_{2}\right)$, nutrient addition (Nutrients) and their interactions on the $\mathrm{C}: \mathrm{N}$, carbon concentration $(\mu \mathrm{mol} / \mathrm{mg})$, and nitrogen concentration ( $\mu \mathrm{mol} / \mathrm{mg}$ ) within tissues of both Ulva and Fucus grown in monoculture (a) and biculture (b). P-values that are significant $(\mathrm{P} \leq 0.05)$ are in bold.

a.

\begin{tabular}{|c|c|c|c|c|c|c|c|c|}
\hline \multirow[b]{2}{*}{ Model Source } & \multicolumn{4}{|c|}{ Ulva } & \multicolumn{4}{|c|}{ Fucus } \\
\hline & $\mathrm{df}$ & SS & $F$ & $P$ & df & SS & $F$ & $\mathrm{P}$ \\
\hline$C: N$ & \multirow[b]{2}{*}{1} & \multirow[b]{2}{*}{1.75} & \multirow[b]{2}{*}{0.23} & \multirow[b]{2}{*}{0.64} & \multirow[b]{2}{*}{1} & \multirow[b]{2}{*}{24.39} & \multirow[b]{2}{*}{2.85} & \multirow[b]{2}{*}{0.11} \\
\hline$p \mathrm{CO}_{2}$ & & & & & & & & \\
\hline Nutrients & 1 & 242.2 & 31.87 & $<0.0001$ & 1 & 57.18 & 6.70 & 0.02 \\
\hline $\begin{array}{l}\mathrm{pCO}_{2} \mathrm{X} \\
\text { Nutrients }\end{array}$ & 1 & 1.65 & 0.22 & 0.65 & 1 & 10.01 & 1.17 & 0.29 \\
\hline Error & 18 & 136.8 & & & 20 & 171.1 & & \\
\hline $\begin{array}{l}\text { C } \\
\text { concentration } \\
(\mu \mathrm{mol} / \mathrm{mg})\end{array}$ & \multirow[b]{2}{*}{1} & \multirow[b]{2}{*}{126.1} & \multirow[b]{2}{*}{5.37} & \multirow[b]{2}{*}{0.03} & \multirow[b]{2}{*}{1} & \multirow[b]{2}{*}{463.7} & \multirow[b]{2}{*}{4.22} & \multirow[b]{2}{*}{0.05} \\
\hline$p \mathrm{CO}_{2}$ & & & & & & & & \\
\hline Nutrients & \multirow{2}{*}{$\begin{array}{l}1 \\
1\end{array}$} & 8.45 & 0.36 & 0.56 & 1 & 118.0 & 1.07 & 0.31 \\
\hline $\begin{array}{l}p \mathrm{CO}_{2} \mathrm{X} \\
\text { Nutrients }\end{array}$ & & 34.42 & 1.47 & 0.24 & 1 & 3.23 & 0.03 & 0.87 \\
\hline Error & 18 & 422.5 & & & 20 & 2197 & & \\
\hline $\begin{array}{l}\mathrm{N} \\
\text { concentration } \\
(\mu \mathrm{mol} / \mathrm{mg})\end{array}$ & & & & & & & & \\
\hline $\mathrm{pCO}_{2}$ & 1 & 0.22 & 1.42 & 0.25 & 1 & 0.53 & 2.52 & 0.13 \\
\hline Nutrients & 1 & 1.14 & 6.66 & 0.02 & 1 & 0.94 & 4.45 & 0.04 \\
\hline $\begin{array}{l}\mathrm{pCO}_{2} \mathrm{X} \\
\text { Nutrients }\end{array}$ & 1 & 0.23 & 1.34 & 0.26 & 1 & 0.01 & 0.07 & 0.80 \\
\hline Error & 18 & 3.09 & & & 20 & 4.20 & & \\
\hline
\end{tabular}

b.

\begin{tabular}{|c|c|c|c|c|c|c|c|c|}
\hline & \multicolumn{4}{|c|}{ Ulva } & \multicolumn{4}{|c|}{ Fucus } \\
\hline Model Source & $\mathrm{df}$ & SS & $\mathrm{F}$ & $P$ & $\mathrm{df}$ & SS & $F$ & $P$ \\
\hline C:N & & & & & & & & \\
\hline$p \mathrm{CO}_{2}$ & 1 & 20.46 & 1.81 & 0.20 & 1 & 0.20 & 0.04 & 0.85 \\
\hline Nutrients & 1 & 65.08 & 5.75 & 0.03 & 1 & 128.1 & 22.44 & 0.0002 \\
\hline $\begin{array}{l}\mathrm{pCO}_{2} \mathrm{X} \\
\text { Nutrients }\end{array}$ & 1 & 13.30 & 1.17 & 0.29 & 1 & 0.05 & 0.01 & 0.93 \\
\hline Error & 18 & 203.8 & & & 17 & 97.05 & & \\
\hline $\begin{array}{l}\mathrm{C} \\
\text { concentration }\end{array}$ & & & & & & & & \\
\hline
\end{tabular}




\begin{tabular}{|c|c|c|c|c|c|c|c|c|}
\hline$(\mu \mathrm{mol} / \mathrm{mg})$ & & & & & & & & \\
\hline$p \mathrm{CO}_{2}$ & 1 & 6.82 & 0.37 & 0.55 & 1 & 4.72 & 0.23 & 0.64 \\
\hline Nutrients & 1 & 116.8 & 6.30 & 0.02 & 1 & 1.70 & 0.08 & 0.78 \\
\hline $\begin{array}{l}\mathrm{pCO}_{2} \mathrm{X} \\
\text { Nutrients }\end{array}$ & 1 & 37.67 & 2.03 & 0.17 & 1 & 0.18 & 0.01 & 0.93 \\
\hline Error & 18 & 333.7 & & & 17 & 353.5 & & \\
\hline \multicolumn{9}{|c|}{$\begin{array}{l}\mathrm{N} \\
\text { concentration } \\
(\mu \mathrm{mol} / \mathrm{mg})\end{array}$} \\
\hline$p \mathrm{CO}_{2}$ & 1 & 0.17 & 1.01 & 0.33 & 1 & 0.003 & 0.03 & 0.86 \\
\hline Nutrients & 1 & 1.31 & 7.98 & 0.01 & 1 & 0.40 & 5.32 & 0.03 \\
\hline $\begin{array}{l}\mathrm{pCO}_{2} \mathrm{X} \\
\text { Nutrients }\end{array}$ & 1 & 0.003 & 0.02 & 0.89 & 1 & 0.0001 & 0.001 & 0.97 \\
\hline Error & 18 & 2.95 & & & 17 & 1.29 & & \\
\hline
\end{tabular}


Algae + OA Manuscript: Figures

Fig.1 (A-D): Mean algal growth rates (\% g day $\left.{ }^{-1}+/-\mathrm{SE}\right)$. Ulva lactuca monoculture (A), F. vesiculosus monoculture (B), U. lactuca biculture (C), and F. vesiculosus biculture (D).

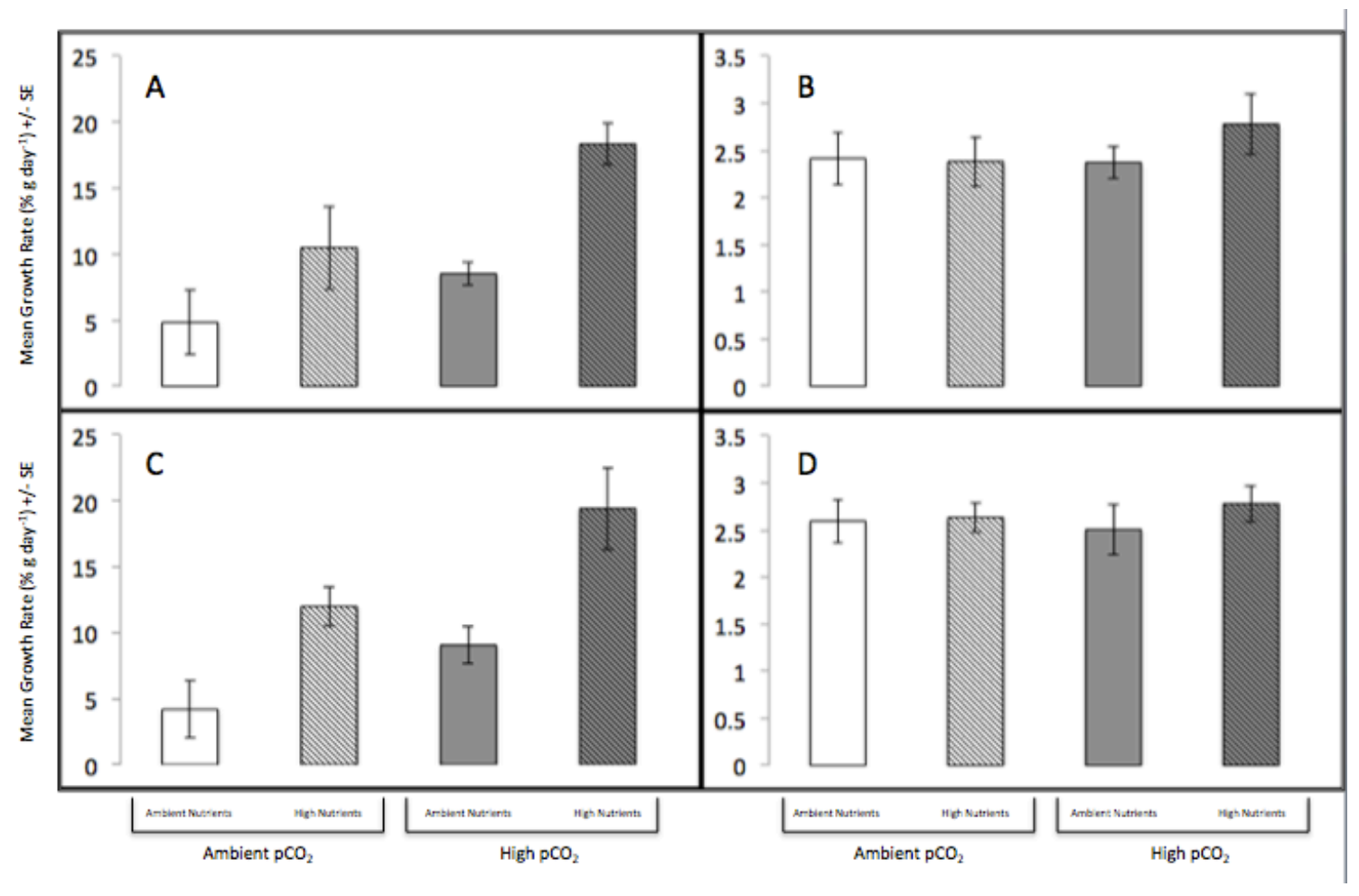


Fig.2 (A-D): Mean algal C:N Ratios (+/- SE). Ulva lactuca monoculture (A), F. vesiculosus monoculture (B), U. lactuca biculture (C), and F. vesiculosus biculture (D). We observed a significant, negative effect of nutrient addition on the C:N of both Ulva and Fucus ( ${ }^{* *}$ represents $p<0.0001$ ). In addition, we observed a significant difference between the C:N of Fucus tissue by culture treatment where C:N was lower in monoculture (C $<$ D, p . 0.002).

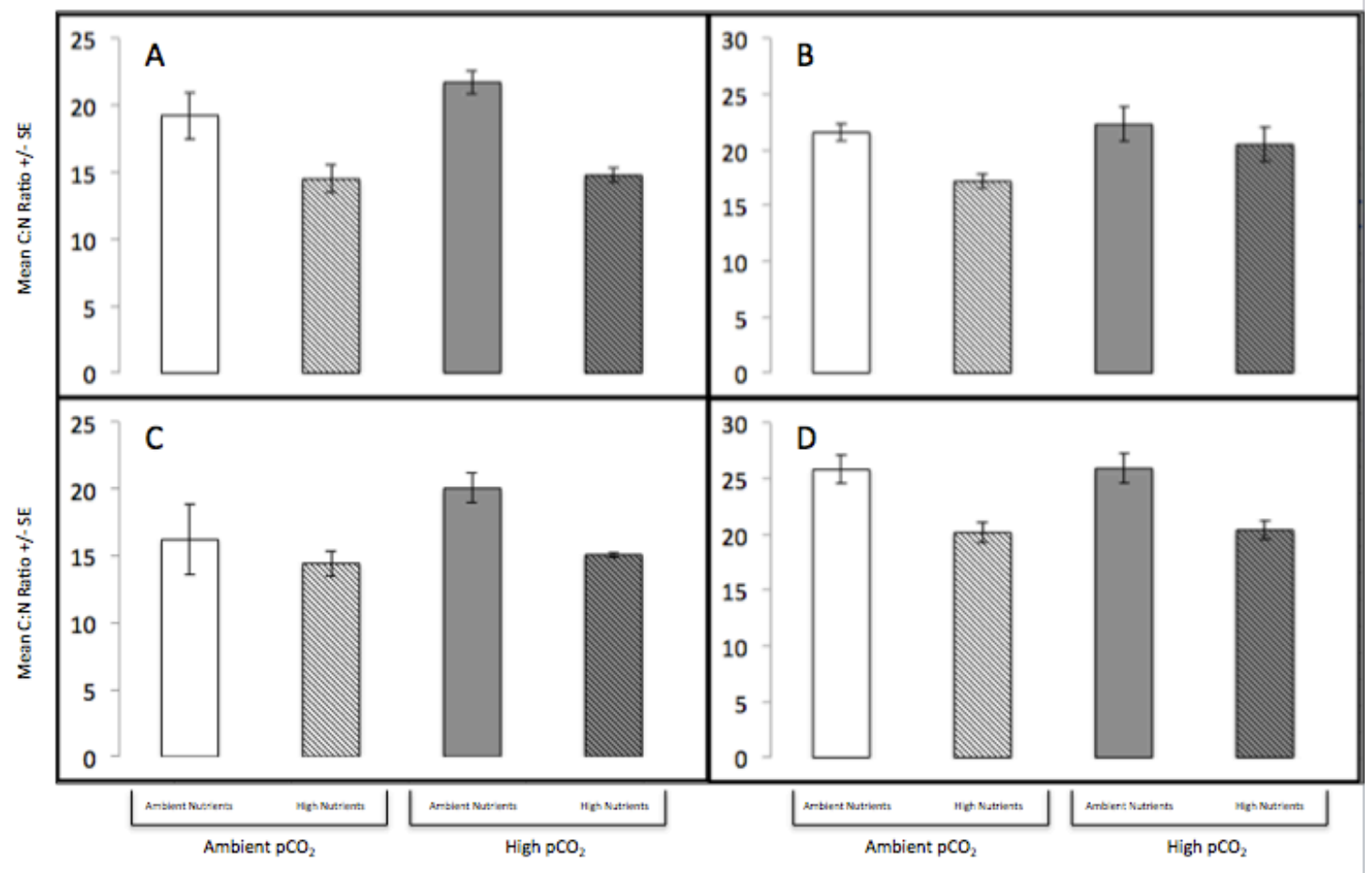

Figure 3A + B: Carbon and Nitrogen Concentrations in U. lactuca (A) and F. vesiculosus (B) by treatment. Ambient pCO2 and ambient nutrients (open circles), Ambient pCO2 and high nutrients (closed circles), high pCO2 and ambient nutrients (open triangles), and high pCO2 and high nutrients (closed triangles). 


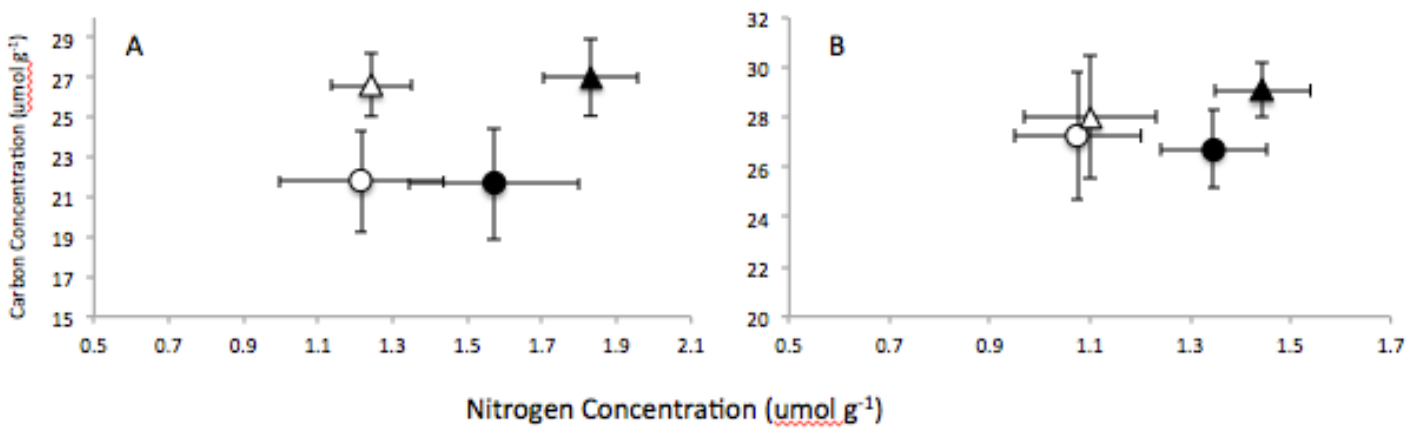

